\title{
HATING WEALTH AND WIVES? \\ AN EXAMINATION OF DISCIPLESHIP ETHICS \\ IN THE THIRD GOSPEL
}

Christopher M. Hays

\begin{abstract}
Summary
The Gospel of Luke often couples instructions on the proper use of wealth with teachings on family relations, sometimes addressing these topics in a tone that smacks of antipathy. The present essay contends that the twin 'hostilities' towards wealth and family in the Gospel of Luke derive from theological roots, specifically, from Luke's endorsement of the imitation of Christ and his teaching on eschatological judgement. To support this thesis, and to delineate certain contours of Lukan ethics, this investigation offers examinations of Luke 9:57-62; 14:25-35; and 17:20-35.
\end{abstract}

\section{Introduction}

With the essay 'Die Armut der Jünger in der Sicht des Lukas' HansJosef Klauck noted that the themes of poverty and celibacy in the Lukan Gospel frequently occur in close conjunction. ${ }^{1}$ Convinced that this interrelationship was no coincidence, Klauck went on to argue that the concurrence of the two themes indicated that they functioned analogously; just as Luke endorsed both celibacy and marriage as acceptable behaviours for followers of Jesus, so also Klauck averred that renunciation of possessions and generous use of wealth are viable forms of discipleship. ${ }^{2}$ Thus Klauck offered a dualistic solution to the thorny issue of Lukan wealth ethics which is broadly similar (though

1 Hans-Josef Klauck, 'Die Armut der Jünger in der Sicht des Lukas' in Amt, Gemeinde, Sakrament: Neutestamentliche Perspektiven, ed. Hans-Josef Klauck (Würzburg: Echter, 1989): 184.

2 Klauck, 'Die Armut der Jünger', 191-92. 
argued on quite different grounds) to that of Hans-Joachim Degenhardt before him, ${ }^{3}$ and, more recently, Kyoung-Jin Kim. ${ }^{4}$ It is not the intention of the present essay to evaluate Klauck's account of Lukan wealth ethics, nor in such a short scope to offer an alternative solution to this bone of scholarly contention. Rather, I would like to suggest that the ethical topics of riches and family are such happy bedfellows in the Third Gospel (particularly in Luke 9:57-62; 14:25-35; and 17:20-35) because they are directly borne upon by two theological subjects important to Luke, viz., the imitation and the expectation of Christ. While these theological themes are only two pillars supporting Luke's lofty ethical edifice, they do contribute to an account of discipleship that does not disavow one's biological relations or despise all manner of possessions, but rather subordinates conventional preoccupations with finances and family to the supreme call of following after Jesus.

\section{Three Would-Be Disciples (Luke 9:57-62)}

The first passage of our study, Luke 9:57-62, offers a series of instructions on discipleship, which serve as a launch pad for the sending of the Seventy (10:1-11). In this pericope, Luke introduces three eager would-be disciples. The first man approaches Jesus and volunteers, 'I will follow you wherever you go.' 6 Jesus responds obliquely to the inquirer, 'Foxes have holes, and birds of the air have nests; but the Son of Man has nowhere to lay his head' (9:57).

That the Son of Man has nowhere to lay his head refers to Jesus' homelessness, an (at least occasional) consequence of his itinerant ministry. ${ }^{7}$ While self-inflicted homelessness is not without precedent, ${ }^{8}$

3 Hans-Joachim Degenhardt, Lukas, Evangelist der Armen: Besitz und Besitzverzicht in den Lukanischen Schriften: Eine Traditions- und Redaktionsgeschichtliche Untersuchung (Stuttgart: Katholisches Bibelwerk, 1965).

4 Kyoung-Jin Kim, Stewardship and Almsgiving in Luke's Theology (Journal for the Study of the New Testament Supplement Series 155; London: Sheffield Academic, 1998).

5 The two themes also seem linked in Luke 18:18-30; 20:20-40.

6 All quotations are from the NRSV unless otherwise indicated.

7 Note also the resonance with Elijah's journey through the desert in $1 \mathrm{Kgs} \mathrm{19:1-8}$; Thomas L. Brodie, 'Luke 9:57-62: A Systematic Adaptation of the Divine Challenge to Elijah (1 Kings 19)', Society of Biblical Literature Seminar Papers 28 (1989): 237-45, esp. 240. 
it is not characteristic of later rabbinic ministry and would have been a hard life, evoking suspicion and antipathy (Sir. 36:31). ${ }^{9}$ Contextually, this description of Jesus' homelessness articulates that his followers will enjoy the same difficult conditions that accompany unemployed itinerancy: frequent lack of shelter and social contempt.

When Jesus approaches a second aficionado and says, 'Follow me,' the man is compliant, asking only for a concession to first bury his father. In First Century Jewish circles, burial took place quickly, generally on the day of death; ${ }^{10}$ if the man's father had recently died, the delay requested would be negligible. ${ }^{11}$ It was the mark of piety to bury the dead, ${ }^{12}$ and a responsibility especially incumbent upon a son. ${ }^{13}$ According to Leviticus, even priests could defile themselves to bury their parents or siblings and children (Lev. 21:1-3; cf. Ezek. 44:25) though the High Priest (Lev. 21:11) and Nazirites (Num. 6:6) still

8 Compare to the Cynics in Epictetus, Diatr. 3.22.45-48; Julian, 6.195b; Anacharsis, Ep. 5; Crates, Ep. 18; Abraham J. Malherbe, The Cynic Epistles: A Study Edition (Missoula, MT: Scholars, 1977): 42-43, 68-69.

9 On the sociological dynamics of insiders and outsiders in the village scene, see Howard Moxnes, The Economy of the Kingdom: Social Conflict and Economic Relations in Luke's Gospel (Eugene, OR: Wipf and Stock, 1988): 52-55.

10 Cf. Acts 5:6-10; 8:2; Josephus, B.J. 3.377; 4.317; S. Safrai, 'Home and Family' in The Jewish People in the First Century: Historical Geography, Political History, Social, Cultural and Religious Life and Institutions, ed. S. Safrai and M. Stern (Amsterdam: Van Gorcum, 1976): 774; Arland D. Jacobson, 'Divided Families and Christian Origins' in Gospel behind the Gospels: Current Studies on Q, ed. Ronald A. Piper (Supplements to Novum Testamentum, 75; Leiden: E.J. Brill, 1995): 362.

11 Depending on how much weight one gives to rabbinic texts, burial may also have been followed by seven days of intense lament and thirty days of less severe mourning; Safrai, 'Home and Family', 782; Bryon C. McCane, "Let the Dead Bury Their Own Dead": Secondary Burial and Matt 8:21-22', Harvard Theological Review 83 (1990): 31-43, esp. 34-35.

12 Tob. 1:17-18; 2:4; 12:12-13; Sir. 38:16; Josephus, C. Ap. 205; m. Ketubbot 11.1; see also Aristides, Apol. 15.8; Tertullian, Apol. 39.6. Interestingly, the author of Tobit parallels the piety of burying the dead to that of sharing meals with the poor (Tob. $1: 17 ; 2: 2-3)$. Its importance is underscored by the persistent mention of the burials of the patriarchs and their families; Gen. 25:9-10; 35:19, 29; 47:29-30; 41:29-31; 50:5-14, 26; see also 2 Sam. 21:10-14 and the conclusions to the Testaments of the Twelve Patriarchs.

13 Gen. 46:4; Tob. 4:3-4; 6:15; Jub. 23.7; 36.1-2,18; note especially Deut. 21:18-21 and Josephus C. Ap. 206 which say that a son who fails to properly bury his parents is to be stoned; Safrai, 'Home and Family', 773; Martin Hengel, The Charismatic Leader and His Followers (Edinburgh: T\&T Clark, 1981): 9-10. In Greek literature, see Philostratus, Vit. Apoll. 13; Euripides, Phoen. 1319. 
lacked this permission. ${ }^{14}$ Conversely, failure to be buried is an exceptional disgrace; ${ }^{15}$ and at times the deliberate neglect of burial is a sign of judgement. ${ }^{16}$ As such, Jesus' response to the second inquirer, 'Let the dead bury their own dead, but as for you, go and proclaim the Kingdom of God' threatened potent Jewish social sentiments. ${ }^{17}$

Though space precludes us from examining the development of scholarly thought on this passage, ${ }^{18}$ the terms of the modern discussion having been set by Martin Hengel ${ }^{19}$ and been more recently reevaluated by Markus Bockmuehl ${ }^{20}$ and Crispin Fletcher-Louis. ${ }^{21}$ Suffice it to say, partially following Bockmuehl's line, the prohibition of burial of the dead for Nazirites and High Priests 'does provide a plausible Jewish context in which the instruction to "let the dead bury

14 Consequently, one line of early interpretation of this logion associated Jesus' prohibition with his calling disciples to a new high priesthood (Tertullian, Marc. 4.23; Mon. 7).

152 Kgs 9:10, 34-35; Jer. 22:19; Mark 12:8; Rev. 11:7-10; 2 Macc. 5:10; 1QM 11.1; 1 En. 98.13; Pss. Sol. 2.27; 4.19-20; Josephus, Ant. 10.97; B.J. 2.465; 3.377; 4.317, 324, 360-61, 382-85. Leif E. Vaage, 'Q and the Historical Jesus: Some Peculiar Sayings (7:33-34, 9:57-58, 59-60, 14:26-27)', Forum 5 (1989): 159-76, esp. 169-70. Fletcher-Louis concludes that it was 'on occasion, a self-conscious act of piety to leave other Jews - "apostates" - unburied as a deliberate declaration of divine punishment and excommunication' (Crispin H. T. Fletcher-Louis, "Leave the Dead to Bury Their Own Dead": Q 9.60 and the Redefinition of the People of God', Journal for the Study of the New Testament 26 (2003): 39-68, esp. 66) though he hastens to add that Jesus' statement need not indicate that the dead man in the story be precluded a burial, only that his son not be the one to provide it, thus cautioning against an overly harsh reading of Jesus' command (Fletcher-Louis, 'Leave the Dead', 68). While it remains unclear who specifically would have buried the man's father, there is little doubt that he would have been buried, in light of the virtue associated with the burial of the dead. Safrai also notes the existence of charitable groups whose purpose was to care for the dead and assist those in mourning (Safrai, 'Home and Family', 775), though there is no solid evidence that these groups existed in the First Century.

16 Ezek. 24:15-24 and Jer. 16:1-9; Darrell L. Bock, Luke 1:1-9:50, vol. 1 (Baker Exegetical Commentary on the New Testament; Grand Rapids: Baker, 1994): 981.

17 On the Cynic disparagement of burial and mourning, see Lucian, Men. 17; Demon. 65; Luct. 19; Arnold A. T. Ehrhardt, 'Lass die Toten ihre Toten begraben', Studia Theologica 6 (1953): 128-64, esp. 131; Hengel, Charismatic Leader, 6.

18 For a summation of the debate before Hengel, see Hans G. Klemm, 'Das Wort von der Selbstbestattung der Toten', Novum Testamentum 16 (1974): 60-75, esp. 68-73; for a delineation of the debate post-Hengel, see Markus Bockmuehl, Jewish Law in Gentile Church: Halakhah and the Beginning of Christian Public Ethics (Grand Rapids: Baker Academic, 2000): 23-26; Fletcher-Louis, 'Leave the Dead', 39-40.

19 Hengel, Charismatic Leader, 3-15.

20 Bockmuehl, Jewish Law, 23-48; Markus Bockmuehl, “'Leave the Dead to Bury Their Own Dead": A Brief Clarification in Reply to Crispin H.T. Fletcher-Louis', Journal for the Study of the New Testament 26 (2003): 241-42.

21 Fletcher-Louis, 'Leave the Dead', 39-68. 
their own dead" can be understood by way of analogy'.22 Certainly this demand is a radical one, which would have aroused significant surprise and even consternation. However, if both Nazirites and High Priests were prevented from burying their parents, then Jesus' logion would not have been completely sui generis in the first-century Palestinian context.

A proper assessment of this logion would benefit from an analysis of the Lukan view of the family. On the one hand, the frequency with which Luke depicts healthy, conventional family dynamics ${ }^{23}$ bespeaks a significant degree of assent to traditional intrafamilial relations. Luke seems generally to endorse existing family structures ${ }^{24}$ and he reflects concern for families in adversity. ${ }^{25}$ Even the language of God as Father $(6: 36 ; 9: 26 ; 10: 21-22 ; 11: 2,13 ; 12: 30 ; 22: 29,42 ; 23: 34,46 ; 24: 49)$ and Jesus as God's Son $(2: 49 ; 3: 22 ; 10: 22)$ capitalises upon the desirability of paternal affection.

Nonetheless, Luke does challenge typical familial relationships, sometimes with disconcertingly hostile rhetoric, though this tendency seems to be engaged in the service of four themes:

1. Freedom for ministry (the disciples, who left family to follow Jesus [18:28-30]; Anna, the widow prophetess, who was in the temple night and day [2:36-37]; Joanna, wife of Chuza, who followed Jesus [8:3]). ${ }^{26}$

2. Luke also seems to express antipathy towards family in order to underscore the importance of extending to others the type of love and reciprocity which were generally limited to kinship relations

22 Bockmuehl, Jewish Law, 47; italics mine.

23 Note the interactions between Mary and Elizabeth $(1: 39-45,56)$, the joy over Elizabeth's bearing of John (1:57-58), Mary's affection for Jesus $(2: 7,19,51)$, sleeping together as a family (11:7), the father's love for the prodigal son $(15: 20-24)$, the vineyard owner's son $(20: 13,15-16)$.

24 Consider Jesus' submission to his parents (2:51), the importance of paternal authority implied in the tale of the prodigal son $(15: 29-30)$, the citation of the fifth commandment (18:20); cf. the genealogy, evincing a traditional concern with paternal roots (3:23-38). See further 1:17; 11:11-13.

25 Healing of Simon's mother-in-law (4:38), the widow's son (7:11-15, esp. vv. $12,15)$, Jairus' daughter $(8: 41-42,51)$; the exorcism of the demon-possessed child (9:37-42, esp. vv. 38, 42); Dives' concern for the fate of his brothers $(16: 25)$; woes to the women nursing when Jerusalem is to be destroyed (21:23).

26 On discipleship as a voluntary association and the sociological interactions with the household, see Adriana Destro and Mauro Pesce, 'Fathers and Householders in the Jesus Movement: The Perspective of the Gospel of Luke', Biblical Interpretation 11 (2003): 211-38, esp. 213-16; note also their thesis that demographically, the first disciples were male and female, married and single, but not household leaders (Destro and Pesce, 'Fathers and Householders', 224-25). 
(as in the banqueting instructions of ch. 14, in which the listeners are not to invite brothers and relatives to banquets, but those who cannot reciprocate the invitation [14:12]; 'If you love those who love you, what credit is that to you?' [6:32]). ${ }^{27}$

3. The primacy of commitment to God/Jesus ${ }^{28}$ ("A woman...said to him "Blessed is the womb that bore you and the breasts that nursed you!" But Jesus said, "Blessed rather are those who hear the word of God and obey it!"' [11:27-28]; Jesus leaves his family to be in his Father's house [2:48-49]; perhaps also 1:62; cf. Acts 5:29), for God is the true Father and true family are those who do the will of God (8:19-21; compare Philo, Leg. 1:52; QE 2:29).29

4. Intra-familial conflict over Jesus (as when Jesus prophesies that the disciples' relatives would deliver them up to the authorities [21:1617]; division within households [12:51-53; cf. Micah 7:6] $]^{30}$; two in bed together, one of whom is taken, the other is left [17:34]; cf. 1 En. 100:1-2; m. Sotah 9:15; Gos. Thom. 16), ${ }^{31}$ which is part of a larger trajectory of division within Israel over their rejection of Jesus and the movement towards the Samaritans and Gentiles (2:34; $3: 8$ [cf. 16:27-30]; 4:24; 10:30-37; 15:11-32 [cf. 15:1-2]; 17:11-19).

This particular logion reflects the concerns of the first and third themes: Jesus exhorts the would-be disciple to leave his father's burial to others, in order to be at liberty to proclaim the Kingdom of God, to

27 Moxnes, Economy, 129-34; Destro and Pesce, 'Fathers and Householders', 221.

28 The subordination of family is also probably implicit in the discussion of the resurrection of the dead; 20:27-36; N. T. Wright, Jesus and the Victory of God (Christian Origins and the Question of God; London: SPCK, 1996): 402.

29 In Judaism it was a well-worn theme that love of parents and family was secondary to love of God and Torah; Exod. 32:25-29; Deut. 13:6-11; 33:9; 2 Macc. 15:18; 4 Macc. 16:24; 4Q175.14-17; Josephus, Ant. 1.222-36; 3.87-88, 211; 6.122-27; Philo, Leg. 2.51; Mos. 1.300-304; 2.171, 273; Spec. 1.316-17; 3.124-27; m. Bava Meși'a 2.1; b. Bava Mesi'a 32a; Yebamot. 5b; Num. Rab.8.3; Roy A. Harrisville, 'Jesus and the Family', Interpretation 23 (1969): 425-38, esp. 431-32; Stephen Barton, Discipleship and Family Ties in Mark and Matthew (Society for New Testament Studies Monograph Series, 80; Cambridge: Cambridge University Press, 1994): 23-44, 54-55. For this reason, proselytes were lauded; Ruth 2:11; Jub. 11.16-18; Jos. Asen. 11.3-14; Philo, Virt. 214; Abr. 67; Barton, Discipleship and Family Ties in Mark and Matthew, 27, n.18. Similarly, the Rabbis talk about having responsibility to one's teacher before one's parents ( $m$. Neziqin 2.11 ; $b$. Horayot 13a;) and pagans affirmed the same with respect to philosophy (Xenophon, Mem. 1.2.49-55; Epictetus, Diatr. 3.3.3-5; 3.22.4549; Isocrates, Chreia 41; Musonius Rufus, Must One Obey One's Parents under All Circumstances?; M. Eugene Boring et al., ed., Hellenistic Commentary to the New Testament (Nashville: Abingdon, 1995): 221-22).

30 Ieuan Ellis, 'Jesus and the Subversive Family', Scottish Journal of Theology 38 (1985): 173-88, esp. 176; see especially Destro and Pesce, 'Fathers and Householders', 219-20 on this passage as a description of intergenerational conflict.

31 Harrisville, 'Jesus and the Family', 426. 
which commitment must remain unrivalled. ${ }^{32}$ Jesus tells his followers to abandon the obligations of this age, since they are the responsibilities of those who are spiritually dead; the disciple must be committed to the Kingdom of God.

The third would-be disciple asks of Jesus only the chance to say goodbye ${ }^{33}$ to his family (Luke 9:61), but Jesus responds, 'No one who puts a hand to the plough and looks back is fit for the Kingdom of God' (9:62). The scenario is reminiscent of 1 Kings 19 (cf. Josephus, Ant.

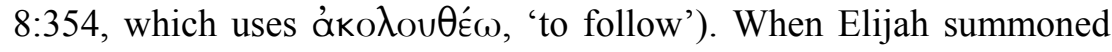
Elisha, the latter was ploughing. Elisha responded that he would gladly follow Elijah, if only he could first kiss his parents goodbye (19:20), which Elijah permitted him (19:21). But whereas Elijah allowed Elisha to bid farewell to his parents, Jesus granted no such freedom to this would-be disciple. This is part of a much larger Elijah motif in Luke, emphasising the supremacy of Jesus over Elijah. ${ }^{34}$ Jesus' superiority to Elijah entails a more radical degree of commitment for his disciples. ${ }^{35}$

What did Jesus mean by telling the would-be disciple, who only wanted to say goodbye to his parents, that 'No one who puts a hand to the plough and looks back is fit for the Kingdom of God'? The problem with looking back while ploughing is that the furrow becomes crooked. ${ }^{36}$ Paul uses the phrase 'the things behind' (то̀ órí $\sigma \omega$ ) similarly, referring to the preconversion occupations that would distract him from seeking 'the prize' (Phil. 3:13-14; cf. Heb. 12:1-3). The commitment required of the disciple surpasses all other relationships

32 Ed Christian, 'Hate Your Family and Carry Your Cross: A Doctrine of Discipleship', Journal of the Adventist Theological Society 10 (1999): 259-67, esp. 262.

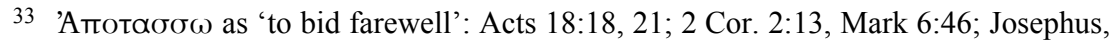

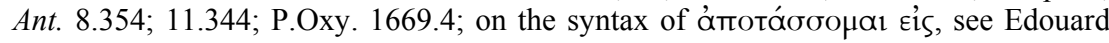
Delebecque, 'Sur un Hellénisme de Saint Luc', Revue Biblique 82 (1980): 590-93, esp. 591-92.

34 9:30-33 implies the superiority of Jesus to Moses and Elijah (9:30-33); 9:51 refers to Jesus' assumption in terms suggestive of Elijah (cf. 2 Kgs 2:11; 1 Macc. 2:58; Sir. 48:9; Robert Doran, 'The Divinization of Disorder: The Trajectory of Matt 8:20/Luke 9:58/Gos Thom 86' in Future of Early Christianity: Essays in Honor of Helmut Koester, ed. Birger A. Pearson (Minneapolis: Fortress, 1991): 217); 9:54 rejects Elijah's practice of destroying his enemies by fire (2 Kgs 1:10-14).

35 Otto Glombitza, 'Die christologische Aussage des Lukas in seiner Gestaltung der drei Nachfolgeworte Lukas IX 57-62', Novum Testamentum 13 (1971): 14-23, esp. 21 22; Brodie, 'Divine Challenge', 237-45.

36 Cf. Journeyings of Philip the Apostle ('O Philip, whosoever putteth his hand to the plough, and looketh backwards, is his furrow well set?'); Hesiod, $O p$. 442-43; cf. Sir. 38:25-26. 
and obligations; attendance to family ties quickly deteriorates into 'looking at the things behind', which fails to benefit the Kingdom. ${ }^{37}$ Within the motifs of freedom for ministry and the surpassing commitment required by Jesus, Luke recapitulates the theme of the second logion. Nonetheless, Jesus' proverb is underdetermined in its reference, so that it avoids directly maligning family ties, but provides a contrastive context for the emphatic obligations of discipleship.

Both of the concessions requested by the would-be disciples were reasonable, even admirable. But Jesus counters these reasonable expectations with a radical summons, pushing beyond what even Elijah demanded (1 Kgs 19:19-21), since he is greater than Elijah (Luke 9:3035). Discipleship is the ultimate commitment, relative to which all other values are reassessed. ${ }^{38}$ Specifically, discipleship to Jesus confronts commitments to family and the security of stable employment, subordinating both to the greater good of following the Messiah.

\section{The Demands of Discipleship (Luke 14:25-35)}

After the tale of the three would-be disciples paints wealth and family ethics in imitation of Jesus' own behaviour, a series of three conditions for discipleship clarifies the picture. In the first of his three sayings, Jesus requires that a disciple 'hate his father and mother, his wife and children, his brothers and sisters-yes, even his own life' (14:26 NIV). Hating one's own life is a distinctive Lukan theme (compare 9:24) and

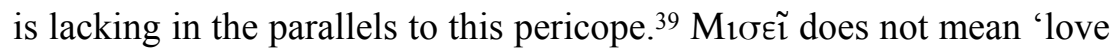
less' 40 and often (but not always) carries the real emotional vehemence of the modern term 'hate.' ${ }^{41}$ However, following the Semitic usage, the

37 John Nolland, Luke 9:21-18:34 (Word Biblical Commentary; Dallas: Word Books, 1993): 543.

38 Robert C. Tannehill, The Sword of His Mouth, ed. William A. Beardslee (The Society of Biblical Literature Semeia Supplements, 1; Philadelphia: Fortress, 1975): 159.

39 Matt. 10:35; Gos. Thom. 55 and 101; Robert H. Stein, 'Luke 14:26 and the Question of Authenticity', Forum 5 (1989): 187-92, esp. 191.

40 Peter G. Jarvis, 'Expounding the Parables: The Tower-Builder and the King Going to War (Luke 14:25-33)', Expository Times 77 (1965-1966): 196-98, esp. 196.

41 Compare the parallel usage of katappové $\omega$ ('to despise') in 16:13; so also Ps. 139:21-22; Josephus, B.J. 2.139; cf. 1QS 1.10; 9.21; Joseph A. Fitzmyer, The Gospel according to Luke $(X-X X I V)$ : Introduction, Translation, and Notes (Anchor Bible; New York: Doubleday, 1985): 1063; Nolland, Luke, 762. 
term $\mu 1 \sigma \varepsilon ́ \omega$ (Heb: ששנא) can also refer to behaving toward someone or something in a negligent or deleterious fashion, which might otherwise imply hate. ${ }^{42}$ This is the nuance intended in $14: 26$; $^{43}$ one's overwhelming commitment to Christ might require a neglect of family that could be construed as hatred. This logion serves as a generalisation of Jesus' earlier instruction for a would-be disciple not to bury his father; in the Jewish worldview, neglecting the burial of one's father would seem to express hatred. ${ }^{44}$ Nonetheless, this 'hatred' is not a psychological hostility, but a behavioural consequence of commitment to Jesus. ${ }^{45}$

This logion is situated in the centre of the thematic streams of Luke's apparent hostility towards family. Most pointedly, it reminds us of the antipathy which would be aroused in traditional Jewish families by allegiance to Jesus (from above, theme 4). This 'hostility' would necessitate a type of behaviour and abandonment that could easily be construed as hating family. Though such freedom for ministry (theme 1) appears absurd, bordering on impossible, ${ }^{46}$ it is essentially parallel to Jesus' own behaviour, since he also abandoned his own mother and brothers to fulfill his Messianic vocation. ${ }^{47}$

Nonetheless, the logion's significance is not exhausted with mere reference to situations in which a disciple's family is not like-minded. It is granted that intrafamilial conflict would be substantially lessened in a family of disciples sharing a similar allegiance to Jesus. Yet the logion's force persists, because Jesus remains prioritised over family (theme 3). As such there will be times and tasks which require the disciple to do what is best for the Kingdom first, though it may even be painful for family members (so Simeon's prophecy to Mary: 'a sword will pierce your own soul too' [2:35]) ${ }^{48}$

42 I.e. 'To be a partner of a thief is to hate one's own life' (Prov. 29:24); 'those who spare the rod hate their children' (Prov. 13:24). So also Gen. 20:30-31, 33; Deut. 21:15-17; Judg. 14:16; 15:2; see also Prov. 1:22, 29; 11:16; 19:6-7; Job 34:17; Sir. 33:2; 1 Macc. 11:21-22; Mic. 3:2; Mal. 3:1; John 15:12, 24; Rom. 9:13.

43 David Peter Seccombe, Possessions and the Poor in Luke-Acts (SNTU Series B, 6; Linz: A. Fuchs, 1982): 106-107.

44 Vaage, 'Peculiar Sayings', 172.

45 Degenhardt, Lukas, 106; Fitzmyer, Luke, 1063.

46 Christophe Singer, 'La difficulté d'être disciple: Luc 14.25-35', Études Théologiques et Religieuses 73 (1998): 21-36, esp. 27.

47 Seccombe, Possessions and Poor, 109; Jacobson, 'Divided Family', 364; Luke $2: 34-35 ; 8: 19-21$.

48 This is precisely how Clement of Alexandria, Quis. div. 22-23 interprets 14:26. 
The second condition of discipleship is that one must take up a cross and follow Jesus (14:27). The phenomenon of a criminal carrying his own cross was a common one (Plutarch, Mor. 554); ${ }^{49}$ Epictetus recognised that crucifixion was a logical consequence of ideological iconoclasm (Epictetus, Diatr. 2:2:20; see also Plato, Resp. 361E362A). As in the parallel command in Luke 9:23, this cross-bearing

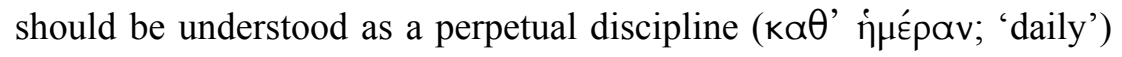
of suffering and self-denial, ${ }^{50}$ possibly entailing even one's own death.

Adding to the gravity of these two conditions, Luke appends two parables with parallel themes. First, the parable of the tower builder describes a man who, before building a tower, calculates the expense the endeavour will require, for fear that he will get the foundation laid and then run out of money, becoming the laughing stock of the community. ${ }^{51}$ The second parable tells of a king considering going to war, who first calculates whether or not he has the resources to win. If not, he sends an embassy to ask for terms of peace (tà mpòs

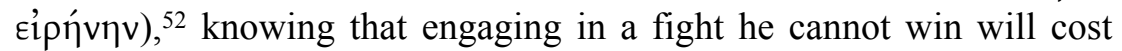
him his kingdom, his men, and maybe his own life. ${ }^{53}$ Simply put, the parables underline the importance of soberly considering whether or not one is capable of committing to discipleship, which entails a hatred of family and bearing of the cross. ${ }^{54}$ Further, the consequences of failure in the parable parallel the consequences of relinquishing one's discipleship. Like the tower-builder, one who abandons Christ will be humiliated, shamefaced as they recant their convictions in Jesus, whom they thought to be the Messiah. ${ }^{55}$ But the dire consequences of the

49 The question over the historical plausibility of Jesus' anticipation of his own means of death is a worthy one, but exceeds the scope of this essay; see Seccombe, Possessions and Poor, 111-12.

50 Degenhardt, Lukas, 108.

51 Thomas E. Schmidt, 'Burden, Barrier, Blasphemy: Wealth in Matt 6:33, Luke 14:33, and Luke 16:15', Trinity Journal 9 (1988): 171-89, esp. 179; cf. Syr. Men. 344.

52 See also 2 Kgdms 8.10, T. Jud.9.7; Fitzmyer, Luke, 1066

53 Bock, Luke, 1292; Michael P. Knowles, "Everyone Who Hears These Words of Mine': Parables on Discipleship (Matt 7:24-27//Luke 6:47-49; Luke 14:28-33; Luke 17:7-10; Matt 20:1-16)' in Challenge of Jesus' Parables, ed. Richard N. Longenecker (Grand Rapids: Eerdmans, 2000): 292.

54 For a similar injunction to consider one's capacities within the context of moral discourse, see Epictetus, Diatr. 3.15; Philo, Abr. 105; Nolland, Luke, 763.

55 The parables of 14:28-32 have also been read 'Christocentrically', suggesting that the tower-builder and the king going out to war represent, not the disciple, but God/Christ, whose reasoned consideration means that the mission of Christ and the Church will not fail; so C. H. Hunzinger, 'Unbekannte Gleichnisse Jesu aus dem Thomas-Evangelium' in Judentum, Urchristentum, Kirche: Festschrift für Joachim 
latter parable, death and the loss of a kingdom, seem to allude to the eternal consequences of abdicating discipleship; while the allusion is only implicit here, it is placed in sharp relief in 14:34-35.

Being the third in the series and only attested by Luke, ${ }^{56}$ the requirement that disciples abandon all possessions is the ethical highpoint of the pericope. With impersonal objects ớrotó $\sigma \sigma \omega$ means

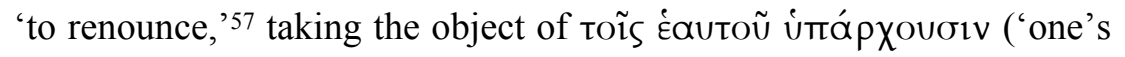
one possessions'); the neuter plural participial form of úmá $\rho \chi \omega$ always refers to possessions in the New Testament. ${ }^{58}$ Although scholars frequently claim that this passage enjoins no more than 'readiness' to give up possessions, ${ }^{59}$ there is no grammatical or contextual indication

Jeremias, ed. Walther Eltester (Beihefte zur Zeitschrift für die Neutestamentliche Wissenschaft und die Kunde der Älteren Kirche; Berlin: Alfred Töpelmann, 1960): 209-220; Jarvis, 'Expounding the Parables', 197-98; J. Duncan M. Derrett, 'Nisi Dominus Aedificaverit Domum: Towers and Wars (Luke XIV 28-32)', Novum Testamentum 19 (1977): 241-61, esp. 258. The most recent and best exponent of this alternative reading is Crispin Fletcher-Louis (Crispin H. T. Fletcher-Louis, 'Jesus Inspects His Priestly War Party (Luke 14.25-35)' in The Old Testament in the New Testament: Essays in Honour of J.L. North, ed. Steve Moyise (Journal for the Study of the New Testament Supplement Series, 189; Sheffield: Sheffield Academic Press, 2000)), but at present Fletcher-Louis' work cannot be given the discussion it deserves.

56 Fitzmyer, Luke, 1061; Klauck, 'Die Armut der Jünger', 177; Vincenzo Petracca, Gott oder das Geld: Die Besitzethik des Lukas (Tübingen: Francke, 2003): 159.

57 As in 2 Clem. 6.4 'this one talks about adultery and corruption and greed and deceit, but that one renounces these things'; see also 2 Clem. 6.5; 16.2; Josephus, Ant. 11.232; Philo, Leg. 3.142-45 (with possessions); Deus 147-51; P.Oxy. 904.8. The semantic range of årtoтó $\sigma \sigma \omega$ and its particular meaning in Luke 14.33 are discussed in greater detail in my forthcoming doctoral dissertation Quis Dives Salvetur: The Coherence and Character of Wealth Ethics in the Gospel of Luke and the Acts of the Apostles.

58 Luke $8: 3 ; 11: 21 ; 12: 15,33,44 ; 16: 1 ; 19: 8$; Acts $4: 33-34$; on the rest of the New

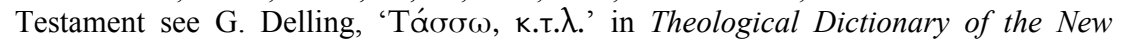
Testament, vol. 3, ed. Gerhard Kittel (Grand Rapids: Eerdmans, 1965): 33 n. 3.

59 Seccombe, Possessions and Poor, 116; Christian, 'Discipleship', 263. Similarly, Petracca claims that this condition of discipleship is merely symbolic, a preconversional exhortation directed towards the Interessentenkreise (circle of interested potential Christians; Petracca, Gott oder das Geld, 160). Repentance is merely a matter of 'disentanglement' (Loslösung) from possessions and social constraints (161). However, Petracca offers no evidence for this symbolic reading or for his contention that the command is only directed to the would-be Christians. The examples of divestiture by true disciples in Luke's Gospel $(5: 11,28$; cf. 18:22) seem to militate against Petracca's preconversional, symbolic interpretation. This appeal to a specific constituency in the audience is a trapping of the reader-oriented dimensions of Petracca's textual-pragmatic approach. In contrast, older German interpreters posited either a vocational, literary, or historical delimitation of the commands for complete divestiture, recognising the poignantly concrete referent of this prerequisite for discipleship (Degenhardt, Lukas, 105; Luise Schottroff and Wolfgang Stegemann, Jesus von Nazareth: Hoffnung der Armen (Stuttgart: Verlag Kohlhammer, 1978): 99- 
that this is the case. Moreover, such an interpretation shows its inadequacy as a method of behavioural exhortation when applied to any other ethical imperative of the New Testament (love of neighbour and enemy, hospitality, evangelism; cf. James 2:16). 'To define action as readiness; or worse, to define inaction as potential action, is to mock the process of sanctification. ${ }^{6} 6$

This third condition of discipleship is coupled with a parable on perseverance in discipleship, and the threat of grave repercussions for retreat (14:34-35); like salt that loses its savour, the disciple who fails to adhere to Jesus' ethical commands will be cast outside. What does it mean to be cast 'outside'? Certainly, the surface reference is to being discarded, thrown away. However in related Lukan contexts, '̌ $\xi \omega$ ('outside') serves as a potent metaphor for rejection from the Kingdom of God (Luke 14:15, 24) and is described as a place of weeping and gnashing of teeth $(13: 25,28)$. Read in its narrative context, the parable warns that failure to bear up under the demands of discipleship (hatred of family, carrying of the cross, renunciation of wealth) results in being excluded from the Kingdom of God.

Thus, Luke 14:25-35 demands careful consideration of two points: the cost of discipleship and the stakes. Discipleship entails a commitment to Jesus that surpasses all other concerns, thrusting the follower into a neglect of family, even conflict with family, personal suffering, and abandonment of possessions, just as Jesus himself experienced. If disciples relent from their discipleship, they will be cast outside in the eschatological judgement. Nonetheless, the conditions of discipleship cannot be ignored; they are the inevitable result of a truly profound love of Jesus above all.

\section{Pre-Parousia Discipleship (Luke 17:20-35)}

The account of the three would-be disciples in Luke 9 broadly adjures the imitation of Jesus in the spheres of wealth and family; Jesus' three conditions for discipleship in Luke 14 hone the ethic into more pointed moral injunctions and a razor sharp warning against relenting from

100; Klauck, 'Die Armut der Jünger', 177). Unfortunately, giving a specific account of the concrete entailments of 14:33 would go well beyond the confines of the present essay.

60 Schmidt, 'Burden, Barrier, Blasphemy', 182. For a materially minimalist reading of this passage, see Cyprian Dom. or. 19. 
discipleship. But the eschatological discourse of Luke 17:20-35, a passage virtually never brought to bear on this debate, situates these discipleship ethics in their eschatological context and further elaborates why Luke has so rigorously inveighed against kin and possessions.

Luke sets up this ethical/eschatological segment by having the Pharisees voice their curiosity about the time in which the Kingdom of God would appear (Luke 17:20). ${ }^{61}$ Without going into detail on the Lukan conception of the Kingdom of God, it suffices to say that Jesus rejects the Pharisaic tendency to speculate about the arrival of the Kingdom of God and the Messiah (17:20-21) ${ }^{62}$ by asserting that the Kingdom of God is already among them (Éviòs úf $\tilde{\omega} v)$. Turning from the Pharisees to his disciples, Jesus warns them not to go after other would-be Messiahs (17:22-25), on the grounds that Jesus' return, ushering in the Kingdom, would not be localised, but immediately known across the world, like lightning which 'flashes and lights up the sky from one side to the other'63 (17:24).

Especially probative for the current investigation, however, are the Old Testament allusions which Luke engages to illustrate Jesus' eschatological parousia. Jesus offers the examples of the generation of Noah and the people of Sodom as analogies (katà tà aưtá) ${ }^{64}$ for the time preceding his coming, likening the 'days of Noah' $(17: 26)$ and the 'days of Lot' (17:28) to the 'days of the Son of Man'. ${ }^{65}$ Since the phrase 'the days of Noah/Lot' refers to the time leading up to the judgement and destruction associated with their respective protagonists, it seems natural to understand the 'days of the Son of

61 Strobel argued that this is a polemic against the Pharisaic tradition that the Messiah was to return on the eve of the Passover (August Strobel, 'Die Passa-Erwartung als urchristliches Problem in Lc 17,20f', Zeitschrift für die neutestamentliche Wissenschaft und die Kunde der älteren Kirche 49 (1958): 157-96, esp. 164-74), but does not substantiate the presence of this theme in the First Century (Fitzmyer, Luke, 1160; Nolland, Luke, 852; Bock, Luke, 1413).

621 En. 91, 93; 2 Bar. 53-74; b. Sanhedrin 97a-98a; Pesiq. Rab. 1.7; Franz Mussner, “"Wann kommt das Reich Gottes?": Die Antwort Jesu nach Lk 17,20b.21', Biblische Zeitschrift 6 (1962): 107-111, esp. 110.

63 Perhaps best translated 'from under the heavens into the heavens,' highlighting the way that lightning strikes and the flash lights up the whole sky. For similar phrases to

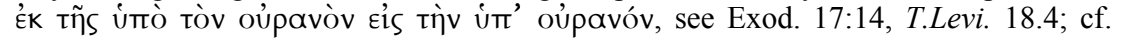
Mussner, 'Wann kommt das Reich Gottes?'; Fitzmyer, Luke, 1170. On lightning flashing from one side of the sky to another, see Dionysius of Halicarnassus, 2.5.2.

64 The same phrase occurs in 6:23, 26, meaning 'in the same way'; cf. Gen. 45:22.

65 For the range of interpretive options on this phrase, see Bock, Luke, 1427-28. 
Man' as the period after the crucifixion of Christ but before his parousia. ${ }^{66}$

What is the import of Luke's free allusion to Noah's generation, which was destroyed by the flood (Gen. 6:11-13; 7:23), and to Sodom and Gomorrah, which were destroyed by fire and sulphur (Gen. 19:17, 24-29)? While commentators frequently understand these tales as illustrations of the unexpectedness of the Messiah's arrival, ${ }^{67}$ the traditional exposition of these stories in Jewish literature uses them to underline the certainty of judgement or inveigh against the sins which lead to the judgement. ${ }^{68}$ While I do not want to completely reject the notion of suddenness, ${ }^{69}$ which seems implied by elsewhere in Luke (Luke 12:35-38, 42-46; 19:12-27, all of which utilise the motif to underscore the importance of proper ethics before the parousia), in what follows I would like to articulate a largely overlooked aspect of the pericope: its significance for ethics.

In the prophets and intertestamental literature, as well as the rabbis, the accounts of the generation of the flood (cf. Isa. 54:9) and the destruction of Sodom and Gomorrah became exemplars of divine judgement against human wickedness. ${ }^{70}$ Consequently, the two stories were paired together with great frequency. ${ }^{71}$ As the quintessential

66 Rudolf Schnackenburg, 'Der eschatologische Abschnitt Lk 17,20-37' in Mélanges bibliques en hommage au R.P. Béda Rigaux, ed. A -L Descamps and André de Halleux (Gembloux, Belgium: J. Duculot, 1970): 226; Fitzmyer, Luke, 1168. On the hope of the revelation of Christ, see 1 Cor. 1:7; 2 Thess. 1:7; 1 Pet. 1:7, 13; 4:13.

67 August Strobel, 'In dieser Nacht (Luk 17,34): Zu einer älteren Form der Erwartung in Luk 17,20-37', Zeitschrift für die neutestamentliche Wissenschaft und die Kunde der älteren Kirche 58 (1961): 16-29, esp. 18; Schnackenburg, 'Der eschatologische Abschnitt', 232; Lars Hartman, 'Reading Luke 17,20-37' in Four Gospels: Festschrift Frans Neirynck, ed. F. van Segbroeck (Bibliotheca Ephemeridum Theologicarum Lovaniensium, 100; Louvain: Peeters, 1992): 1667; Norman Mundhenk, 'Problems Involving Illustrations in Luke', Bible Translator 44 (1993): 247-48, esp. 247; John Topel, 'What Kind of a Sign Are Vultures? Luke 17,37b', Biblica 84 (2003): 403-411, esp. 407.

68 J. Schlosser, 'Les jours de Noé et de Lot: À propos de Luc 17:26-30', Revue Biblique 80 (1973): 13-36, esp. 14.

69 Although it bears mention that there is no indication in the Noah account that the building of the ark was a secret to Noah's neighbours, and in the Sodom account Lot does warn his sons-in-law, albeit to no avail (19:14).

70 For such a usage of the destruction of Sodom, see Deut. 29:23; 32:33; Isa. 1:9-10; 3:9; 13:19; Jer. 23:14; 49:18; 50:40; Lam. 4:6; Ezek. 16:46-56; Amos 4:11; Zeph. 2:9; 3 Macc. 3:4-5; Wis. 2:9.

71 For the pairing of the Noah and Sodom accounts, see Wis. 10:4-6; 3 Macc. 3:4-5; Sir. 16:7; T.Naph. 3.4-5; Jub. 20.5; Hel. Syn. Pr. 8.3; 4Q180; Philo, Mos. 2.53-56 263; 2 Pet. 2:5-8; Jude 6-7 (alludes not to Noah but to Gen. 6:1-4); Pesiq. Rab. 9.3; 40.1 [these two include Babel]; 42.3,8 [with Babel]; Sipre Num. 18.1; Mekilta de-Rabbi 
figures for judgement, their wicked deeds are generally enumerated, sometimes at graphic length. The generation of Noah was accused of a panoply of corruptions, ${ }^{72}$ but sins related to greed ${ }^{73}$ and lust ${ }^{74}$ figure significantly in the lists. Nonetheless, Luke does not accuse them of any salacious activities; he benignly describes them as eating and

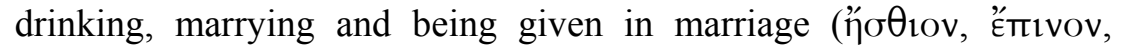

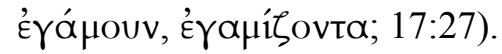

As one might imagine, Sodom was accused of an equally impressive litany of corruption, ${ }^{75}$ but again, sins related to greed and oppression appear pervasively, ${ }^{76}$ indeed, as often as sexual sins. ${ }^{77}$ But as with his

Ishmael, Pisha 7.36-41; Pesiq. Rab. Kah. 26.2; Gen. Rab. 27.3; 50.8; Eccl. Rab. 2.2.1 [Attribute of justice]; 2.23.1; Num. Rab. 9.18; 11.7 [these two with Pharaoh]; Lev. Rab. 4.1; 7.6; 23.9); Tanh. Tsaw 2.3; Ahare Mot 6.2; Tanh. Yelammedenu, In the Beginning 12; And the Lord Appeared 9; Midr. Ps. 53.1-2); see also 1 Pet. 3:20; Dieter Lührmann, 'Noah und Lot (Lk 17:26-29)—Ein Nachtrag', Zeitschrift für die neutestamentliche Wissenschaft und die Kunde der älteren Kirche 63 (1972): 130-32, esp. 130.

72 For example: the sin of Cain (Gen. Rab. 22.12; 32.5); pride (Lev. Rab. 7.6; Tanh., Tsaw 2.3); blasphemy with their mouths (Tanh., Noah 2.16); idolatry (Gen. Rab. 28.8); persecuting Noah (Tanh., Emor 8.12); Sorcery (Tanh. Yelammedenu, In the Beginning 12); merely living too long (Tanh., Bereshit 1.40; Midr. Ps. 1.12), or having harvests for many years after sowing (Tanh., Bereshit 1.40).

73 In both early and late documents, the generation of the flood is accused of robbery and injustice (Philo, Mos. 2.53; Gen. Rab. 31.4; cf. Tanh. Yelammedenu, In the Beginning 12); violence and theft (Targ. Neof. Gen. 6.11-13; so also in Tg. Ps.-Jon. Gen. 6:11-13; Tg. Onq. Gen. 6.11-13; Gen. Rab. 31.1-4); general wickedness (4 Ezra 3.8-11; Josephus, Ant. 1.73-75) as a consequence of their affluence (b. Sanh. 108a).

74 The tradition extends from early to late texts, mentioning: lewdness/sexual immorality (Jub. 20.5; T. Naph. 3.4-5 ['departing from the order of nature'] $b$. Temurah 28b; Hullin 23a; Bekhorot 57a; AZ 23b; Sanh. 57a; Tanh. Yelammedenu, In the Beginning 12; Midr. Ps. 53.1; compare this to the tradition that sex was forbidden on the Ark [b. Sanh. 108b; Gen. Rab. 31.12; 34.7]); lust (Gen. Rab. 32.7; b. Zevahim 113b); masturbation (Kallah Rab. 52a; Gen. Rab. 26.4; 32.7); bestiality (b. Sanh. 108a; Tanh., Bereshit 1.21; Noah 2.11; 2.18); combination of violence, robbery, lewdness (Tanna Debe-Elliyahu, EZ 190); writing hymns about sodomy (Lev. Rab. 23.9).

75 Arrogance (Sir. 16:8; 3 Macc. 2:3-5; Tanh., Tsaw 2.3); idolatry (Tg. Neof., Ps.-J. Gen. 13:13); hostility to angels (T.Ash. 7.1); blasphemy (b. Sanh. 109a); general evil (Pesiq. Rab. 42.8; Mekilta de-Rabbi Ishmael, Shirata 5.45-55) or rebellion (Tanh., Beshallah 4.1).

76 Again, note the examples stretching from the Old Testament into the Rabbis: strengthening the hands of the wicked (Jer. 23:14); being arrogant, overfed, apathetic, and oppressing the needy (Ezek. 16:46-56; so also b. Sanh. 104b; Sipre Deut. 318; Pirqe R. El. 25); murder of the innocent, oppression of the poor (Tgs. Ps.-Jon. Gen. 13:13; Tanh. Yelammedenu, And the Lord Appeared 7; see also Tg. Neof. Gen. 13:13); inhospitality (b. Sanh. 109a; Lev. Rab. 7.6; Tanh., Ahare Mot 6.2; cf. Tanh., Wayyera 4.15,22; Pirqe R. El. 25); sin as a result of the corrupting influence of their wealth (Philo, Abr. 228; Tgs. Onq., Ps.-Jon. Gen. 13:13 Lev. Rab. 5.2; b. Sanh. 109a; cf. Schlosser, 'Les jours de Noé', 20). 
description of Noah's contemporaries, in spite of a tradition on Sodom's reprehensible behaviour, Luke mildly remarks once again that they were eating and drinking, buying and selling, planting and

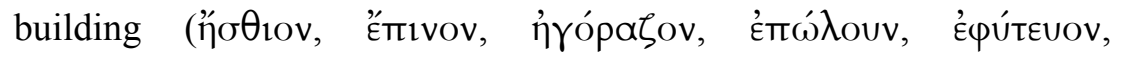

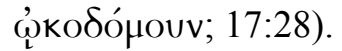

In light of Luke's general agenda to denounce greed and oppression, it is not a surprise that he chose to preserve the Noah material transmitted in the synoptic parallels, and to insert a functionally similar allusion to Lot. What is surprising, however, is the fact that Luke radically mutes the deeds of two groups who generally function as icons of evil. Instead of describing them as a band of violent, lascivious idolaters, as his contemporaries do, Luke portrays their behaviour as that of any upstanding citizen, ${ }^{78}$ thus shifting the accent from the reprehensible deeds that brought about Sodom's judgement, to a more generalised warning on how not to behave in the face of already certain judgement. Against the background of casual preoccupation with business and family with which Luke describes the contemporaries of Noah and Lot, Luke presages the eschatological return of the Son of Man in judgement. The ethical implication of the allusions is that the inevitable return of the Son of Man precludes current preoccupation with business as usual (cf. Luke 10:38-41). ${ }^{79}$

On that day of judgement, Luke instructs, 'anyone on the housetop who has belongings (tò okeún) in the house must not come down to take them away; and likewise anyone in the field must not turn back' $(17: 31)$. Luke uses these images to underscore the danger that attachment to possessions poses in the face of judgement. The caution not to turn back for possessions is especially apt in light of the fact that the generations of Noah and Sodom were said to be rich.

77 Adultery (Jer. 23:14); lust (Philo, Fug. 144); sexual sin (Philo, Mos. 2.55; 2 Pet. 2:7; T. Naph. 3.4-5 ['departing from the order of nature']; Jub. 20.5; Tgs. Ps.-Jon., Neof., Onq. Gen. 13.13; b. Sanh. 109a; Tanh. Yelammedenu, And the Lord Appeared 7; Tanh. Wayyera 4.14); rape (Josephus, Ant. 1.200-202).

78 Tannehill, Sword, 119; Xavier Léon-Dufour, 'Luc 17,33', Revue des Sciences Religieuses 69 (1981): 113-22, esp. 109; Nolland, Luke, 860; Elisabeth Jay, 'Why "Remember Lot's Wife"?: Religious Identity and the Literary Canon' in Literary Canons and Religious Identity, ed. Erik Borgman et al. (Burlington, VT: Ashgate, 2004): 41.

79 Compare the similar pairing of the parousia with the arrival of the Kingdom of God, as well as the judgement motif, in 9:26-27; Hartman, 'Reading Luke 17,20-37', 1666. 
Luke then offers an example of the behaviour against which he warns; he tersely commands, 'Remember Lot's wife' (17:32). With equal vagueness, the Genesis account merely said, 'Lot's wife, behind him, looked back, and she became a pillar of salt' (Gen. 19:26; recall the warning about not 'looking back' in Luke 9:62). The lack of explanation for the transformation of Lot's wife led to a great deal of speculation in Jewish literature, and the various solutions proffered tend to invoke family or financial concerns. ${ }^{80}$ On one hand, the targumic tradition explains, 'because she was from the daughters of the Sodomites she looked back to see what would be the end of her father's house. ${ }^{81}$ Conversely, Philo avers that her gaze was fatefully drawn by the glory, riches, and elegance of Sodom (Philo, Som. 1:248; cf. 86). This association with wealth is not surprising in light of the tradition that Sodom was exceedingly affluent ${ }^{82}$ and punished for neglect and exploitation of the poor in spite of their riches. ${ }^{83}$

Although the traditions surrounding Lot's wife associate her fateful turning more frequently with concern for her family than with concern for wealth, the immediate context of the passage (cf. 17:31: $\mu$ in

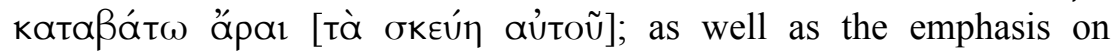
making one's life secure in v. 33) seems to suggest that the preoccupation with possessions is at the forefront of Luke's mind. Nonetheless, being that Luke invokes both the generation of Noah as 'marrying and being given in marriage' and the Sodomites as 'buying and selling,' it is perhaps most balanced to think of the allusion to 'Lot's wife' as conveniently redolent of both the themes of wealth and family. The implications for discipleship are clear: those concerns which tempted Lot's wife to look back, whether her family or the comforts of Sodom, hold the same dangers for a disciple, tempting her to look back at the world which is coming under judgement. ${ }^{84}$

80 Some other suggestions include: she did not use her faculty of reason (Philo, Fug. 121-22; cf. Philo, Eb. 164 where, in this capacity, she is called 'custom'); she was double-minded and distrusted the power and command of God (1 Clem. 11.2).

81 Tg. Neof. Gen. 19:26; see also Tg. Ps.-Jon. Gen. 19:26; Pirqe R. El. 25; Gen. Rab. 51.5.

82 As in Philo, Abr. 227; QG 43; Tgs. Onq., Neof., Ps-Jon. Gen. 13:13; Lev. Rab. 5.2.

83 For example: Ezek. 16:46-56; b. Sanh. 104b, 109a; Sipre Deut. 318; Pirqe R. El. 25; similarly, for lack of hospitality Lev. Rab. 7.6; Tanh., Ahare Mot 6.2; cf. Tanh., Wayyera 4.15,22; Pirqe R. El. 25.

84 In this vein, Clement, Strom. 3.6.49 interprets 17:28 as an exhortation to celibacy. Discussing the same passage, Tertullian, $U x$. 1.5 allows marriage, but sees celibacy as better, and wants those who are married to live in fear of judgement. He also calls 
While the commands not to turn back to one's home are popularly understood to be primarily eschatological in their referent, Luke engages the logia in the service of pre-parousia ethics. This is probable for four reasons. First, at the triumphal parousia of Christ, there would be no reason for disciples to flee or fear for provisions. ${ }^{85}$ Second, the descriptions of two ploughing or grinding together do not indicate that at the parousia time will be available for any preparatory action. Third, this pericope's location in the travel narrative would naturally suggest that it contains teachings on Jesus' suffering vocation and its entailments for discipleship.

Fourth, the interpretation that this passage addresses earthly behavioural ethics is corroborated by the parallel parable in 19:11-27.86 Both pericopae share numerous topics. 19:11-27 refutes expectations of the immediate arrival of the Kingdom of God (19:11), explaining that when Jesus returns after inheriting the Kingdom (19:12), he will bring judgement upon his enemies (19:27) and reward his faithful servants $(19: 17,19)$. But the main emphasis of the parable is on serving the king properly throughout his absence, which is the same point that 17:20-37 makes, albeit with greater specificity regarding the expected behaviour. In contrast, the one who does not serve the king wisely (i.e. the one who looks back and is restrained by worldly concerns) will be pronounced a wicked servant. These passages serve parallel purposes: 17:20-37 dispels preoccupation with calculation of judgement day and exhorts proper behaviour in light of that judgement; 19:11-27 is a general parable which draws together all of the teachings on discipleship and assures Jesus' final inheritance of the Kingdom and vindication, in spite of what the coming events in Jerusalem might indicate.

Summarising his ethical teaching, Luke resumes a favourite theme: 'Those who try to make their life secure will lose it, but those who lose their life will keep it' (17:33). The motif occurs repeatedly in the New Testament, ${ }^{87}$ but is never a plan for how to act on the day of judgement,

marriage and buying 'the very leading vices of the flesh and of the world which call men off the most from divine disciplines'.

85 Pace Bock, Luke, 1434.

86 It should be remembered that 11-27 follows on the heels of the story of Zacchaeus (19:1-10), who serves as an exemplar of the type of generosity and abandonment of possessions that garners a share in the Kingdom of God (19:9).

87 Luke 9:23-24 (and parallels; cf. Luke 14:26-27); John 12:24-26; 1 Cor. 15:36; note the parallels in Judaism and Hellenism: Syr. Men. 315-319; b. Tamid 32a; Sipre Num. 
but always teaching about how to act today in light of the eschatological judgement and resurrection. This same concept of losing one's life to gain eternal life occurred in 14:27 (and 9:23-24), again, prescribing discipleship ethics. The pattern of Lukan usage militates against a strictly eschatological orientation for 17:33, as well as 17:2037 as a whole. These passages all indicate that concern with preserving one's life, which conventionally is manifested through normal human preoccupation with family and business, is, in the face of the coming judgement, a sure-fire way to incur punishment (see further 9:23-26; 21:19). The only way to avoid perishing in the final judgement is to die to conventional concerns. As such, the discourse in Luke 17:22-33 is eschatologically motivated ethical teaching for the period between the crucifixion and return of the Son of Man.

Luke caps this discourse with an adaptation of the Noah language for the disciples' context, emphasising the certainty of judgement, and thus implying the importance of discipleship in the present. When the Son of Man comes in judgement, of the two people together in a bed or a field, one will be taken ( $\pi \alpha \rho \alpha \lambda \eta \mu \varphi \theta \eta j \sigma \varepsilon \tau \alpha 1)$ and the other will be

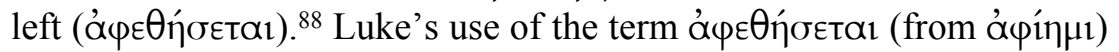
is evocative of the Noah account, in Genesis 7:23 'He blotted out every

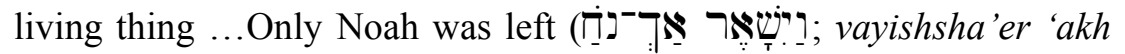
noakh)'. 4 Ezra 3:8-11 and Apoc. Adam 3:5 describe Noah's preservation from the flood in similar terms. Those influenced by modern conceptions of a 'rapture' commonly take vv. 33-34 as a reference to the suddenness of the parousia. However, following on the heels of the account of the ten lepers (17:11-19), and in the broader context that includes the parables of Dives and Lazarus (16:19-31) and the Pharisee and tax collector (18:9-14), the descriptions of one being

25.1 §131; Xenophon, Cyr. 3.3.45; Epictetus, Diatr. 3.20.5-6; cf. Homer, Il. 15.563564; Petr Pokorný, 'Lukas 17,33parr.-Die Geschichte Jesu und ein (damals) bekanntes Sprichwort' in For the Children, Perfect Instruction: Studies in Honor of Hans-Martin Schenke on the Occasion of the Berliner Arbeitskreis für KoptischGnostische Schriften's Thirtieth Year, ed. Stephen Emmel, Hans-Gebhard Bethge, Karen L. King, and Imke Schletterer (Nag Hammadi and Manichaean Studies; Leiden: Brill, 2002): 389-90. So also dying for the sake of the Torah is a theme that occurs frequently in the Talmud: b. Shabbat 83b; b. Berakhot 63b; b. Gittin. 57b expositing Num. 19:14. See further Str-B 1: 587-588.

88 For a similar generic scenario, see b. Rosh HaShanah 18a in which two people are in the same bed with illness, or in court, and one dies while the other lives. 
taken and one being left is best understood as an image of division and judgement (so Irenaeus, Haer. 5:27:1). ${ }^{89}$

If this is about division, then on what basis? Ostensibly, the division would occur on the grounds of the ethics enjoined in the context. By picking up the language of 'left behind' from the Noah account, it is implied that those who are left behind were righteous like Noah, in parallel contradistinction to those of his generation who were preoccupied with 'marrying and being given in marriage'. In light of the coming division of humanity, disciples are to live in such a way as to assure that they, like Noah, are left behind. ${ }^{90}$

Eschewing the eschatological preoccupations of his contemporaries, when Jesus taught about his return in judgement, he gave his followers no dates and times, no logistics or coordinates; rather, he expounded upon how they were to behave while they waited and anticipated him. In so doing, he evoked the stories of Noah and Lot, though engaging these exemplars of iniquity in an ironic way. By emphasising only the common human engrossment with family and business, Luke summons the disciples away from the preoccupations typical of the world, warning them that if they, like Lot's wife, became entangled with family or commerce, they would suffer judgement. In short, they are to act like Jesus, refusing to be captivated by employment and family, in order to be received by him when he returns.

\section{Summary and Conclusions}

The coincidence of ethical injunctions on wealth and family in these three passages in Luke derives from their common theological roots. Luke generates his moral praxis theologically, and in texts taken up by this study, Luke's ethics are, in large part, products of the twin notions of the imitation and expectation of Christ.

89 The rapture concept is patently foreign to this passage, the imagery of which is perfectly understandable in light of the basic Jewish notions of eschatological judgement by the Messiah and the division of the righteous and the wicked. I am grateful to G. K. Beale for pointing out in a lecture at Wheaton College that the 'rapture' language of the Gospels likely derives from the Noah account.

90 Schnackenburg, 'Der eschatologische Abschnitt', 234; Schlosser, 'Les jours de Noé', 35-36; Léon-Dufour, 'Luc 17,33', 110-11; Friedrich Wilhelm Horn, Glaube und Handeln in der Theologie des Lukas (Göttinger Theologische Arbeiten; Göttingen: Vandenhoeck und Ruprecht, 1983): 282. 
The theme of the imitation of Christ surfaces in the first two sayings to would-be disciples. Jesus warns that discipleship would entail homelessness, lack, and shame as a consequence of living the itinerant lifestyle that accompanied following him. Similarly, though the theme of imitation of Christ is writ large throughout the Travel Narrative, in no place is this motif so pronounced as in Luke's repeated assertion that discipleship requires taking up one's own cross, hating one's own life, and following Jesus in self-denial (9:23-24; 14:27; 17:25, 33).

So also the expectation of Christ's return in judgement serves as a goad and an enticement towards faithful discipleship. The day of the Son of Man brings about the judgement and division of humanity on the basis of their fidelity to Christ $(14: 34-35 ; 17: 34-35)$. As such, the disciple is spurred towards radical self-denial, leaving behind worldly preoccupations with possessions, employment, and family (17:26-31), and not turning back $(9: 62 ; 17: 31)$, unlike Lot's wife (17:32).

Having located some of Luke's theological moorings, we might say a few words on Luke's specific ethical views. A study like this ought to affirm that Luke values family as a desirable good, but a subsidiary good. The disciple's highest allegiance is owed to Jesus. In situations where the family is divided against Jesus, this might result in dissension and strife. Nonetheless, even if one's family is comprised completely of followers of Christ, there still may be times in which the disciple is required to pursue Christ in such a way that she would seem to hate her family $(14: 26)$. Furthermore, the joys of a spouse and children may become a hazard to the disciple $(9: 59-62 ; 17: 27,32)$, who could easily become preoccupied with family to a degree that he or she would flag in commitment to the proclamation of the Kingdom of God (9:60).

Similar to Luke's family ethics, the Third Gospel's wealth ethics are some of the most demanding in the Bible. Luke warns that the comfort provided by regular and secure employment cannot be guaranteed to a disciple (9:57-58), since engrossment with work is a distraction to discipleship, a perilous entanglement in light of the fact that the Kingdom of God has arrived and Jesus is returning in judgement (17:26-32). Moreover, following Jesus requires a renunciation of wealth (14:33), ${ }^{91}$ both as a general consequence of imitating him and,

91 The discussion of radical divestiture was specifically side-stepped in this essay, and should be examined in more detail in tandem with the accounts of the calling of the 
as the rest of the Gospel expands, because of the dangers of wealth and the demands of love. Luke's Gospel offers an account of discipleship thoroughly shaped by the imperative to imitate Christ, fuelled by the expectation of eschatological judgement, and issuing even in the neglect of security, comfort and family in the service of the Kingdom of God.

disciples $(5: 10-11,27-29)$, the instructions on itinerancy $(9: 1-6 ; 10: 1-11 ; 22: 35-38)$, and the accounts of the Rich Ruler (18:18-30) and Zacchaeus (19:1-10). 